I forbindelse med vaktpostlymfeknuteundersøkelse ved ekstremitetsmelanomer (sentinel node procedure) skriver forfatterne at aksille eller lyske bør undersøkes med ultralyd. Vi mener at det ikke er godt nok. Både primærtumors lokalområde, den regionale lymfeknutestasjonen og området mellom disse bør undersøkes, eventuelt supplert med ultralydveiledet cytologisk biopsi (FNAC) ved mistanke om metastaser.

Først når ultralyd tas med i utredningen av maligne melanomer hvor det allerede ved debut foreligger fare for spredning, har kirurgen de beste forutsetningene for å utføre en mest mulig korrekt kirurgisk prosedyre, hvilket gjør det potensielt mulig å helbrede pasienten.

\section{Arne Heilo}

aheilo@hotmail.no

Olav Inge Håskjold

Arne Heilo (f. 1946) er pensjonert overlege ved Oslo universitetssykehus, Radiumhospitalet.

Ingen oppgitte interessekonflikter.

Olav Inge Håskjold (f. 1962) er overlege ved Klinikk for diagnostikk og intervensjon, Oslo universitetssykehus.

Ingen oppgitte interessekonflikter.

\section{Litteratur}

1. Geisler J, Bachmann IM, Nyakas M et al. Malignt melanom - diagnostikk behandling og oppfølging i Norge. Tidsskr Nor Legeforen 2013; 133: 2154-8.

Dette er en redigert versjon av debatten, publisert på nett 1.11. 2013.

http://tidsskriftet.no/article/3082712/
Norsk Melanom Gruppe (NMG) svarer:

Kommentaren skrevet av Heilo \& Håskjold berører ett av mange viktige, men hittil ubesvarte spørsmål: Hvor mye diagnostikk er nødvendig og tilstrekkelig for pasienter med maligne melanomer?

Ultralydundersøkelser blir allerede i dag brukt som et ledd i diagnostikken av maligne melanomer og virker lovende i noen situasjoner. Imidlertid stiller man i dag høye krav til nye medikamenter, og omfattende dokumentasjon fra store kliniske studier er nødvendig mens man ser på kost-nytte-verdien etc.

Vi i Norsk Melanom Gruppe mener at nye diagnostiske muligheter er viktige og burde utvikles og evalueres på like fot med nye medikamenter før disse anbefales til alle pasienter med maligne melanomer, f.eks. i våre nasjonale anbefalinger. Kliniske studier som avklarer nytteverdien av f.eks. høyfrekvente ultralydundersøkelser - innflytelse på residivrisikoen eller totaloverlevelsen ønskes derfor velkommen!

\section{Jürgen Geisler}

juergen.geisler@medisin.uio.no

Jürgen Geisler (f. 1963) er kontaktperson for NMG, spesialist i onkologi og stråleterapi ved Akershus universitetssykehus og professor i onkologi ved Universitetet i Oslo.

Ingen oppgitte interessekonflikter.

Dette er en redigert versjon av debatten, publisert på nett 8.11. 2013. http://tidsskriftet.no/article/3082712/ 